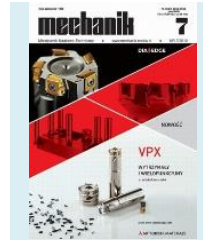

Title of article: „Koncepcja laboratoryjnej wersji symulatora żurawia wiezowego z platformą obrotową do szkolenia operatorów” ("Concept of laboratory version of a tower crane symulator based on rotary platform for training operators")

Mechanik, Vol. 91, No. 7 (2018): pages 594=596

DOI: https://doi.org/10.17814/mechanik.2018.7.94

\title{
Concept of laboratory version of a tower crane simulator based on rotary platform for training tower crane operators
}

\author{
Koncepcja laboratoryjnej wersji symulatora żurawia wieżowego \\ z platformą obrotową do prowadzenia szkoleń operatorów żurawi
}

\section{HUBERT WELENC TOMASZ LIPIŃSKI *}

This paper presents the concept of a laboratory version of tower crane simulator based on rotary platform as a prototype of a device which, after being thoroughly tested and approved by the experts from training agencies, will serve the purpose of training tower crane operators.

KEYWORDS: simulation, tower crane, operator training

Cranes belong to the handling devices that are subject to technical supervision. They are in fourth place among such devices used in Poland (before them there are only: mobile platforms - about 64 thousand, cranes - about 108 thousand, lift trucks - about 114 thousand).

According to the Office of Technical Inspection (hereinafter: UDT), in the group of cranes covered by full surveillance in 2012, eight accidents and 13 dangerous damage to equipment were noted, resulting in death suffered by four people and four injuries (heavy accidents). These events were caused, among others errors made by operators (such as exceeding the permissible load by approx. 159\%, which resulted in the loss of stability and overturning of the crane, or hook stroke with the swaying load).

According to GUS data for 2011-2015, 95 accidents occurred during the use of tower cranes. In comparison with other means of transport, this is a small number, and in addition none of these accidents have led to death or serious injury to operators (fig. 1).

On the other hand, UDT data show that in the years 20102012, as a result of accident situations involving tower cranes, 14 people died, while injuries were suffered by 22 people. Comparing these statistics with GUS data, one can conclude that not only machine operators, but also people cooperating with them are particularly exposed to the risk of losing health or life (fig. 2).

\footnotetext{
* mgr inż. Hubert Welenc (huwel@ciop.pl), Centralny Instytut Ochrony Pracy - Państwowy Instytut Badawczy, mgr Tomasz Lipiński (tolip@ciop.pl), Centralny Instytut Ochrony Pracy - Państwowy Instytut Badawczy
}

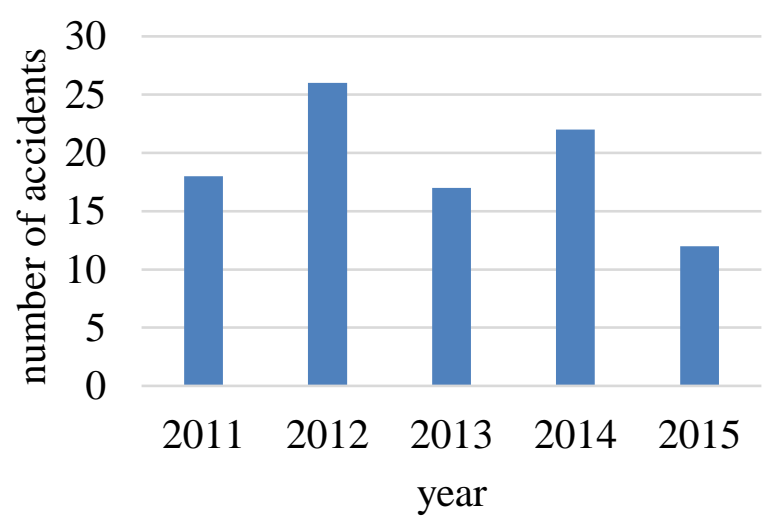

Fig. 1. Histogram showing the number of accidents involving tower cranes in 2011-2015 (source: CSO)

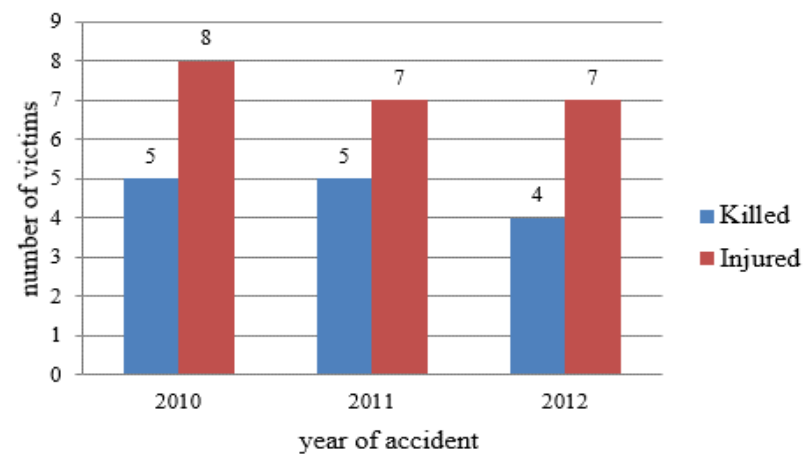

Fig. 2. Histogram showing data on people killed and wounded (not only operators) in accidents involving tower cranes in 2010-2012 (source: UDT) 


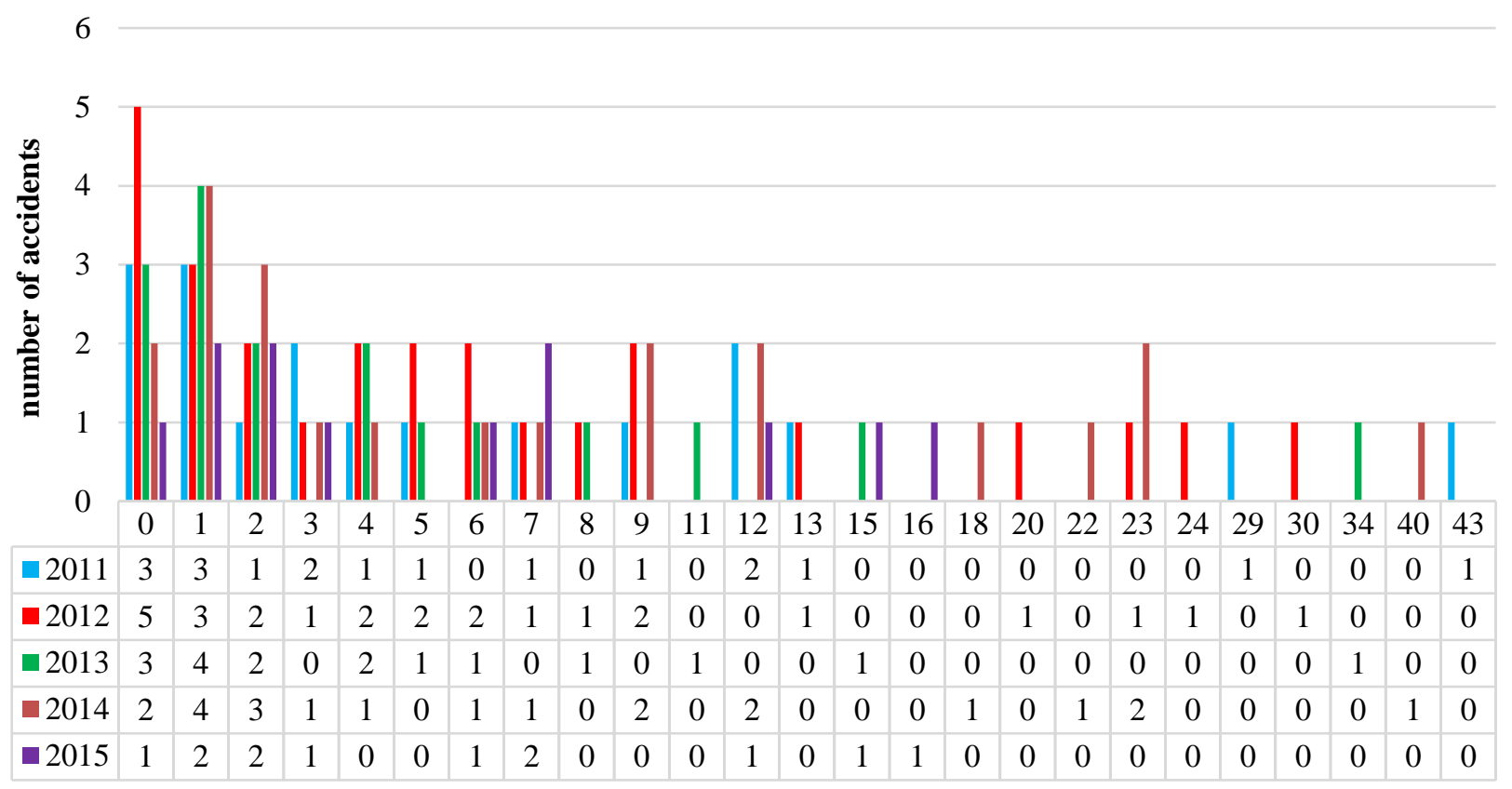

years of seniority

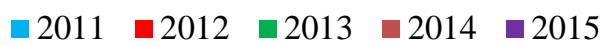

Fig. 3. Histogram presenting data on the number of accidents to which tower crane operators underwent depending on seniority in $2011-2015$

A summary of data presenting the number of accident incidents among transport operators depending on their seniority in this position shows that a relatively large number of accidents occur in a group of people with an internship not exceeding two years. The total number of accidental events in this group reaches even $33 \%$ of all accidents. High percentage of young tower crane operators is also accidents. Among the more experienced employees, there was no clear correlation between the number of accidents and seniority (fig. 3).

\section{Development of assumptions for the construction of a laboratory version of a tower crane (stationary) with a rotating platform}

In the Laboratory of Virtual Reality Technique, a task is carried out under the name "Development of a laboratory version of a tower crane simulator with a rotating platform for conducting crane operator trainings", the aim of which is to create a device with software, designed to conduct training in the use of tower cranes operating in dynamically changing, simulated ambient conditions, and indirectly - improving the safety of operators of tower cranes.

The tower crane simulator will consist of a seat mounted on a rotary shaft rotated around a vertical axis by a servo drive. The whole will be enclosed with a three-dimensional frame made of aluminum profiles, to which four LCD TV sets will be attached using special holders. The devices will be installed so that the person trained on this simulator closes from the front in a visual cage whose walls display the image from the virtual environment in such a way that the person seated on the seat had the impression of immersing in a computer generated world (CAVE technology, fig. 4).

The program layer of the simulator will be executed in the application for creating games and virtual environments of Unity. It is an engine that allows you to render photorealistic images thanks to support for DirectX 11 shaders. In addition, the Unity environment works with the NVIDIA
PhysX engine. It is an SDK tool supported by marketleading system platforms, operating on a multithreaded basis and used to simulate physical phenomena occurring in virtual environments. Using NVIDA PhysX it is possible to simulate mechanics of rigid solids and soft bodies (creation of character controllers), simulation of connections between physical elements, simulation of vehicle dynamics or particle effects [1]. The simulator graphic resources will be created in the Blender and Substance Painter applications.

One of the key objectives of the first stage was to develop a laboratory verification method for the tower crane simulation version so that it could be used to train crane operators. In order for the simulator to pass the verification process it must: be responsive and well balanced, have an intuitive interface (due to which the operator can easily switch to a real machine after the training), correctly simulate physical phenomena related to crane control and load transfer [2], display ( on televisions or in projection glasses) a clear, fluid and synchronized image with platform movements (to minimize the risk of simulation disease symptoms) [3].

The training scenarios used during the training should refer to real works performed by tower cranes and take into account the applicable regulations and safety standards in the evaluation of the trainee's actions. In addition, the scenarios whose outlines were created in cooperation with the training unit will have modifiers that allow you to adjust the level of difficulty of the task, eg by introducing a large number of repetitions, precipitation or wind that hinders stable cargo transport. 


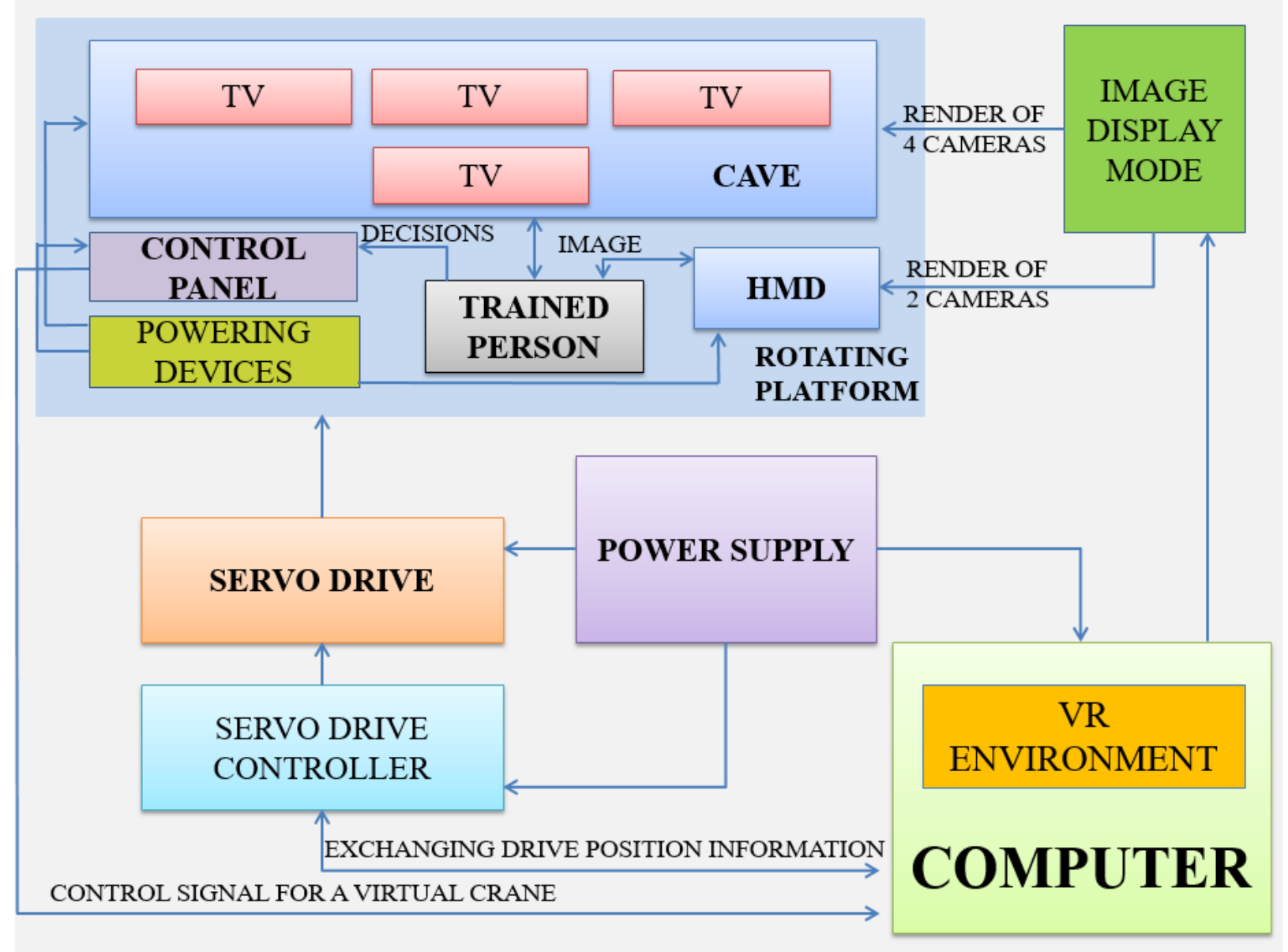

Fig. 4. Block diagram of the simulator

The tests used to verify the simulator will be carried out at the third stage of the task. 21 volunteers from the cooperating training unit will take part in them. These people will be asked to perform on the simulator the same activities related to the use of the crane on the construction site.

Participants will be divided into three groups:

- people trained on a permanent platform without HMD,

- people trained on a rotating platform and in HMD,

- control group, trained on a rotating platform and in the CAVE system.

The evaluation criterion will include proper performance of activities related to the use of the crane according to the UDT Framework Program. Verification of the developed simulator will be carried out with the help of a questionnaire based on the evaluation model of Kirkpatric's training programs. The system evaluation will be carried out according to the Expert Inspection for evaluating Virtual Environments method [4]. It is also planned to use standard questionnaire tools for system evaluation, e.g. System Usability Scale [5]. Participants will also complete a spatial presence questionnaire, measuring, among others, realism of the control process simulation and realism of the virtual environment. The results will be analyzed statistically using Student's t-test, analysis of variance (ANOVA) or KruskalWallis tests.

\section{Conclusions}

A tower crane simulator with a rotating platform in a laboratory version, which is being created in the CIOP-PIB Virtual Reality Technique Laboratory, is to be a device supporting training of tower cranes operators, both beginners and advanced ones, to improve work safety conditions of this professional group. The assumptions for construction, made at the first (already completed) stage of the task implementation, are to contribute to: reliable simulator operation, achieving the immersion impression and eliminating the symptoms of simulant disease. The use of HMD and CAVE systems will allow us to assess which image projection method works better in this type of training application. It is planned to examine the influence of rotary platform motion on: the quality of the training, the obtained impression of immersion and the occurrence of symptoms of simulant disease.

Publication based on the results of the fourth stage of the multiannual program "Improving safety and working conditions", financed in the years 2017-2019 in the scope of tasks of state services by the Ministry of Family, Labor and Social Policy. Program coordinator: Central Institute for Labor Protection - National Research Institute.

\section{REFERENCES}

1. „Unity User Manal". https://docs.unity3d.com/Manual/index.html.

2. Solarz W., Tora G. "Sterowanie napędami żurawia wieżowego". Transport Przemysłowy. 10-12 (2005).

3. Malińska M., Zużewicz K., Bugajska J., Grabowski A. „Subiektywne odczucia wskazujące na występowanie choroby symulatorowej i zmęczenie po ekspozycji na rzeczywistość wirtualną". Medycyna Pracy. 65, 3 (2014): pp. 361-371.

4. Bach C., Scapin D.L. "Comparing inspections and user testing for the evaluation of virtual environments". International Journal of Human-Computer Interaction. 26, 8 (2010): pp. 786-824.

5. Brooke J. "SUS: a 'quick and dirty' usability scale". W: Jordan P.W., Thomas B., Weerdmeester B.A., McClelland A.L. (red.): Usability Evaluation in Industry. London: Taylor and Francis, 1996. 
Translation of scientific articles, their computer composition and publishing them on the website www.mechanik.media.p by original articles in Polish is a task financed from the funds of the Ministry of Science and Higher Education designated for dissemination of science.

Ministry of Science and Higher Education

Republic of Poland 